\title{
IMPROVING STUDENTS' READING COMPREHENSION THROUGH COLLABORATIVE STRATEGY READING AT SMP NEGERI 1 SORONG
}

\begin{abstract}
This research aimed to find out whether or not the application of Collaborative Strategy Reading is effective to improve students' reading comprehension achievement on descriptive text. It involved quantitative research method using quasi-experimental design with nonequivalent control group design. The sample taken from population of the second class of 2015-2016 academic year in SMP Negeri 1 Sorong, it was 24 students for each class. They were class VIII A and class VIII C. The data from students reading comprehension achievement wag gathered through multiple choice test given before and after doing treatment. Data analyzed through descriptive analysis using program of SPSS 20. The data has shown that the application of Collaborative Strategy is effective to improve students' reading comprehension achievement on descriptive text. It's seen form the result of the non-probability test used on Mann Whitney test sig. $0.00<0.05$.
\end{abstract}

Keywords :Reading Comprehension, Collaborative Strategy Reading 


\section{INTRODUCTION}

Reading is a cognitive activity in which the reader takes part in a conversation with the author through the text. On the other hand reading strategies are considered as one of the features of cognitive psychology which are essential for a successful comprehension. Reading is useful for language acquisition provided that students' more or less understand what they read. Based on the background of research, the researcher formulates a research question as follow: "Does the application of Collaborative Strategy Reading is effective to improve students' reading comprehension achievement on descriptive text?"

The purpose of this research is to find out whether or not the application of Collaborative Strategy Reading is effective to improve students' reading comprehension achievement on descriptive text.

\section{REVIEW OF LITERATURE}

The Previous Studies that the researcher in this research by Nosratinia (2013) in Her Research focused on attempt to systematically investigate the effect of teaching collaborative strategy reading approach on intermediate EFL learners' reading comprehension. She found that the experimental group performed statically better in their post test which means that an increase in students' performance in reading comprehension, due to the effect of collaborative strategy reading approach was occurred.

Definition of Collaborative Strategy Reading according to Klingner \& Vaough (1996) is an approach that combines reading strategy instruction and cooperative learning

Reading is a complex cognitive process of decoding symbols in order to construct or derive meaning .It is a means of language acquisition of communication, and of sharing information and ideas.

\section{Reading Comprehension}

Reading Comprehension is defined as the level of understanding of a text or message. This understanding comes from the interaction between the words that are written and how they trigger knowledge outside the text or message. Comprehension is a creative, multifaceted process"

According to Wainwright (2007: 128) stated Reading comprehension is process complex become wrapped around benefit various success or fail ability. After reading, we must able to remember about the information in the text reading. 


\section{Reading Component}

According to Harris (1969) on his book

"Testing English as a Second Language", the abilities needed in reading a language include at least the following:

\section{Language and graphic symbol}

a. Comprehending a large percentage of the lexical items occurring in no specialize writing and being able to derive the meaning of unfamiliar items (or special use of common items) from the contexts in which they occur

b. Understanding the syntactical pattern and morphological forms characteristic of the written language and following the longer and more involved stretches of language (sentences and sequences of sentences) occurring in formal.

The procedure of collaborative strategy reading Summary

This article provides an overview of Collaborative Strategy Reading (CSR) as an approach to enhancing the Reading Comprehension skill of students with learning disabilities. The following three strategies that encompass Collaborative Strategy Reading are presented: preview, get the gist, and wrap-up.
Students learn three strategies as part of Collaborative Strategy Reading, they are:

\section{Before reading:}

1. Preview

a) Brainstorm: What do we already know about the topic?

b) Predict: what do we think we will learn about the topic when we read the passage?

\section{During Reading:}

2. Get and Gist

a) What is the most important person, place, or thing?

b) Where is the place or setting text and also actors on reading text and matters discussed in the reading text?

c) What is the most important idea about the person, place or thing?

\section{After Reading:}

3. Wrap Up

a) Ask questions: what questions would show we understand the most important information?

b) Review: what did we learn?

c) The students repeat, what they have learn today.

Collaborative Strategy Reading in Janned et al (1998:32) according to Lucille Sullivan (1968) is an excellent technique to teach students a reading comprehension and to 
build vocabulary and also to work together cooperatively. In this strategy, students need to work cooperatively in a group. Teacher has a role to provide ongoing assistance. Teacher also actively give help when needed and actively listen to the discussion done by students.

\section{READING COMPREHENSION}

Reading comprehension as important concern to master by student's in teaching and learning process provides some definitions from some experts. They are Woolley, G. (2011) said Reading comprehension is the process of making meaning from text. Reading comprehension not only means the understanding, but also evaluating and utilizing the information and gaining them through an interaction between a reader and an author in which the written language as the medium. Thinker (1975:5) also stated that reading comprehension is not just reading with a loud voice but reading is to understand the meaning of words, sentences and paragraph sense relationship among ideas provided on a text. Based on the experts' explanation, it can be concluded that reading is not only comprehending the meaning of the words, sentence and paragraph provided, but also evaluating and utilizing information gain for the text by paying attention to the relation among them.

\section{There are two hypotheses in this research, they are:}

Null hypothesis $\left(H_{0}\right)$ : The Application of Collaborative Strategy Reading is not effective to improve students' reading comprehension achievement on descriptive text at SMP Negeri I Sorong.

Alternative hypothesis $\left(H_{1}\right)$ : The Application of Collaborative Strategy Reading is effective to improve students' reading comprehension on descriptive text at SMP Negeri I Sorong.

\section{RESEARCH METHODOLOGY}

This research applied quantitative method. Quantitative method is a kind of research method which can be classified concrete, and analyzed (Sugiyono, 2009: 7). In order to answer the research problems, the researcher used quasi experimental design; it is nonequivalent control group design. The research used two classes as sample of this research.

The Population of Research was all students of second grade students of SMP Negeri I Sorong. It was 75 students. They were divided into three classes, class VIII A was 
24 Students, VIII B was 27 students and Class VIII C consisted of 24 students.

The Sample of Research of this research is class VII A and Class VIII C which consisted of 24 students for each class. The sample was taken using un-randomized sampling technique. Class VII $\mathrm{A}$ as the Control Class and Class VIII $\mathrm{C}$ as the Experiment Class.

Multiple choice tests was used in order to obtain the primary data. The procedures of collecting the data are as follows:

\section{Pre-test}

The researcher gave pre test for both of the group, experimental and control group, before giving treatment. The multiple choices reading comprehension test was given for both of the class. It consists of 20 numbers with 4 descriptive texts.

\section{Treatment}

FINDING AND DISCUSSION

\section{Decryption Analysis}

The researcher found out the description analysis using SPSS 20 analysis program.
After the researcher gave the pre test, the researcher collected the data and gave treatment for both of the classes. The treatments were using Collaborative Strategy Reading in Experimental Class and applying the conventional method (Presentation method) in Control Class.

\section{Post-test}

After giving the treatment for them, the researcher gave the post test to know the students' comprehension achievement.

\section{DATA ANALYSIS}

Data analyzed using SPSS 20 program to find out the descriptive analysis, the normality, and the significant differences for both of the class to answer the research question.

The result can be seen in Table 1 . Descriptive Analysis below:

Table 1. Descriptive Analysis

\begin{tabular}{|l|l|l|r|r|}
\hline Result of & Minimum & Maximum & \multicolumn{1}{|l|}{ Mean } & \multicolumn{1}{|l|}{ S. Deviation } \\
\hline Pre Test Experiment & 20 & 50 & 31.67 & 10.901 \\
\hline Post Test Experiment & 30 & 70 & 46.67 & 13.406 \\
\hline Pre Test Control & 60 & 80 & 70.00 & 7.223 \\
\hline Post Test Control & 80 & 90 & 82.50 & 4.423 \\
\hline
\end{tabular}


Based on the data above, in has been revealed that the minimum score of pretest for experimental class was 20 and for control class was 30 . While the maximum score of pretest for both of the experiment and control class were 50 and 80 . The mean score for the two classes shown a big difference in 39 number, the scores were 31.67 and 70.00 for each mean score of the classes. The result of the posttest shown a significant improvement for the experimental class, it was 20 number increased from maximum pretest score 50 became 70 as maximum score. While based on the mean score, the Control class score was higher than the experimental class, it were 82.50 with 4.42 standard deviation score and 46.67 with 13.406 standard deviation score..

\section{Test of Normality}

This research used the normality test to know the normality data gathered. The researcher applied Kolmogrov-Smirnov as the Normality test. This is the result of normality test taken form SPSS 20 analysis program.

\section{Table 2. The Normality Test Result}

\begin{tabular}{|c|c|c|c|c|}
\hline \multirow{2}{*}{\multicolumn{2}{|c|}{ KELAS }} & \multicolumn{3}{|c|}{ Kolmogorov-Smirnov $^{\mathrm{a}}$} \\
\hline & & Statistic & $\mathrm{df}$ & Sig. \\
\hline \multirow{4}{*}{$\begin{array}{l}\text { HASIL } \\
\text { BELAJAR }\end{array}$} & PRE EX & .227 & 24 & .002 \\
\hline & POST EX & .235 & 24 & .001 \\
\hline & PRE CONT & .250 & 24 & .000 \\
\hline & $\begin{array}{l}\text { POST } \\
\text { CONT }\end{array}$ & .464 & 24 & .000 \\
\hline
\end{tabular}

Based on the data shown above, it can be concluded that the data distribution of the data gathered in this research was not normal. It has been proved by the result of normality test, it was lower than 0.05 . when the data distribution is not normal, the nonparametric test must be done. Based on that reason, this research applied the Mann Whitney test to know whether or not the application of Collaborative Strategy Reading is effective to improve the students' reading comprehension on descriptive text using SPSS 20 Analysis program. 
Table 3. The Result of Mann Whitney Test

\begin{tabular}{|c|c|}
\hline & $\begin{array}{c}\text { HASIL } \\
\text { BELAJAR }\end{array}$ \\
\hline Mann-Whitney U & .000 \\
\hline Wilcoxon W & 300.000 \\
\hline $\mathrm{Z}$ & -6.146 \\
\hline Asymp. Sig. (2-tailed) & .000 \\
\hline
\end{tabular}

The result has shown us that the significant result was 0.00. It means that the Sig. $<0.05$. It has been concluded that if the Sig. $<0.05$ the alternative hypotheses was accepted and if the Sig. $>0.05$ the alternative hypotheses was rejected. Based on the result shown, it can be concluded that the application of the Collaborative Strategy Reading is effective

\section{CONCLUSION}

Based on the data analysis gathered, collaborative strategy reading at the second year students of SMP Negeri 1 Sorong is effective to improve students' reading comprehension on descriptive text. The researcher also found that the student's reading comprehension achievement on experimental class still need more investigation. It give unsatisfied achievement to students reading to improve students' reading comprehension on descriptive text in SMP Negeri 1 Sorong. This result is also supported by Rahman (2015) the implementation of Correlative Strategy Reading increased student's reading proficiency at Madrasah Aliyah Negeri 1 Makassar.

comprehension. It can be seen on the minimum score of the post test that only reach 50. It was not suited the minimum criteria to passed the English lesson at school. It suggested for the next researcher who are excited to conduct the similar research to conduct the research on classroom action research method to improve students' reading comprehension on the Experimental class in this research. 


\section{BIBLIOGRAPHY}

Harris, David P.1969. Testing English as a second language.USA:McGrowhillbook company.

Klingner, K Janette \&Voughn, S. 1996. Reciprocal Teaching of Reading Comprehension strategies for Students with Learning Disabilities who Use English as a Second Language.

Nosratinia, Mania. 2013. "Toward a Humanistic instruction: Collaborative Strategy EFL Learners' Reading Comprehension. International Journal of Advanced Studies in Humanities and Social Science. Vol. 1, Issue 8. August.

Sugiono. Dr. Prof. 2009. Metode Penelitian Kuantitatif, Kualitatif, R \& D Bandung. Alfabet

Wainwright, G. 2007. Speed Reading Better Recalling. Jakarta: Pt Gramedia PustakaUtama

Rahman, F. I. 2015. The Implementation of Collaborative Strategy Reading (CSR) and Its Effects on Students' Reading Comprehension. ETERNAL (English, Teaching, Learning, and Research Journal).Vol. 1, Number 01, June 2015.
Janned K. Klingner \& Sharon Vaughn.(1998). Using Collaborative Strategy reading: The council for exeptional children. Teaching Exceptional Children Journal (Online): Juli-August pp. 32-36, downloded on 25 Jan 2011. Thinker, A. Miles and Cullogh, M.Mc Cinstance. 1975. Teaching Elementary Reading. New Jersey. Practice Hall, Inc.

Woolley, G. 2011. Reading Comprehension: Assisting Children with Learning Difficulties, DOI 10.1007/978-94007-1174-7_2, ( ) Springer Science+Business Media B.V. 